\title{
A comparative study between intralesional 5-fluorouracil combined with triamcinolone acetonide and triamcinolone acetonide alone in the treatment of keloids
}

\author{
Karunasree Nagarur ${ }^{1}$, Narasimha Rao Raja ${ }^{2}$
}

\begin{abstract}
${ }^{1}$ Department of Pharmacology, Government Medical College, Nizamabad, Telengana, India ${ }^{2}$ Department of Dermatology, Central Hospital, South Central Railway, Lallaguda, Hyderabad, Telangana, India
\end{abstract}

Received: 10 April 2016

Revised: 14 May 2016

Accepted: 16 May 2016

*Correspondence to:

Dr. Karunasree Nagaru,

Email: raja_narasimharao

@yahoo.com

Copyright: () the author(s), publisher and licensee Medip Academy. This is an openaccess article distributed under the terms of the Creative Commons Attribution NonCommercial License, which permits unrestricted noncommercial use, distribution, and reproduction in any medium, provided the original work is properly cited.

\begin{abstract}
Background: Many modalities of keloid treatment have been advocated which have a variable and transient success. There is no universally accepted treatment resulting in permanent cure. Hence there is need for evaluation of better modalities to achieve good cosmetic acceptability. Current study compares the efficacy and safety of intralesional 5-fluorouracil combined with triamcinolone acetonide and triamcinolone acetonide alone in the treatment of keloids.

Methods: Cases of clinically diagnosed keloids from South Central Railway Hospital were included in the study. These patients were randomly allocated alternately between group 1 and 2. An interventional and comparative study, comparing the percentage reduction in volume of keloid between both groups after treatment was done. For group 1 intralesional injection 5-fluorouracil 0.9 $\mathrm{ml}(50 \mathrm{mg} / \mathrm{ml})$ combined with $0.1 \mathrm{ml}$ of triamcinolone acetonide $(40 \mathrm{mg} / \mathrm{ml})$ i.e., $45 \mathrm{mg}$ of 5 Fluorouracil was combined with $4 \mathrm{mg}$ of triamcinolone, weekly once for 8 weeks. For group 2 intralesional triamcinolone acetonide $10 \mathrm{mg} / \mathrm{ml}$ alone weekly for 8 weeks. Volume of keloid (i.e., (length $\mathrm{x}$ breadth $\mathrm{x}$ height measured by vernier calipers) before starting treatment and one week after the last injection was compared. percentage reduction in the volume was calculated. Results: The overall therapeutic response in volume reduction in group 1 was found to be better and statistically significant ( $\mathrm{p}$ value<0.01) compared to group 2 .
\end{abstract}

Conclusions: The present study has shown that intralesional 5-FU+TAC is more effective compared to TAC intralesional injection alone.

Keywords: Keloid, Intralesional 5-flourouracil, Intralesional triamcinolone acetonide

\section{INTRODUCTION}

Wound healing is a dynamic biological process involving numerous cell to cell and cell to matrix interactions in a complex milieu of local and systemic influences. When the healing process goes awry, one ends up with over healed wounds like keloids.

Keloid is a firm, irregularly shaped, thickened, hypertrophic, fibrous pink or red excrescence. In course of time keloid becomes brown, sometimes hyperaesthetic often it is extremely tender, painful, pruritic, hard and stationary and commonly seen on presternum, shoulder and earlobe. They may be single or multiple and often varying in size and number.

Keloids classically occur on certain parts of the body specifically on the shoulder, anterior chest wall and earlobes. Surface tension and sebaceous gland density are among the characteristics that have been hypothesized to predispose these anatomical sites to keloid formation.

Keloids affect only homo sapiens and may develop even after the most minor of skin wounds such as insect bites, 
acne and injuries. Some individuals report spontaneous keloid formation

Further, keloids rarely regress with time.

There is no universally accepted treatment resulting in permanent disappearance of hypertrophic or keloid scar. Many modalities of treatment have been advocated. Most of these modalities have a variable and transient success.
Hence there is a need for evaluation of the better modalities of treatment to achieve a good cosmetic acceptability.

The objective of this study was to compare the efficacy and safety of intralesional 5-fluorouracil +triamcinolone acetonide with intralesional triamcinolone acetonide alone in the treatment of keloids among patients of age group 10-70 years.

Table 1: Biochemical and molecular differences between hypertrophic scar and keloid.

\begin{tabular}{|c|c|c|}
\hline & Hypertrophic scars & Keloids \\
\hline Collagen bundles & $\begin{array}{l}\text { Fine, well-organized, wavy parallel to } \\
\text { epidermis }\end{array}$ & $\begin{array}{l}\text { Large,thick, closely packed random } \\
\text { to epidermis }\end{array}$ \\
\hline Myofibroblasts & Present & Absent \\
\hline (alpha-SMA expressing) & Nodular formation & Around blood vessel wall) \\
\hline Hyaluronic acid localization & Major component papillary dermis & Thickened, granular/spinous layer \\
\hline Mucin deposition & Negative & Focal expression in dermis \\
\hline ATP level & Low expression & High expression \\
\hline $\begin{array}{l}\text { Amorphous substance on electron } \\
\text { microscopy }\end{array}$ & Absent & Diffuse pattern \\
\hline Apoptosis & Decreased & Increased/decreased \\
\hline p53 level & Low & High \\
\hline
\end{tabular}

\section{Pathomechanism}

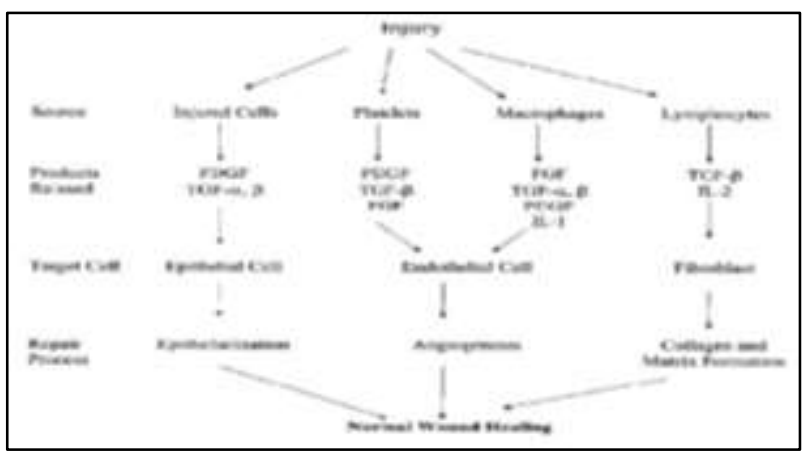

Figure 1: Normal wound healing.

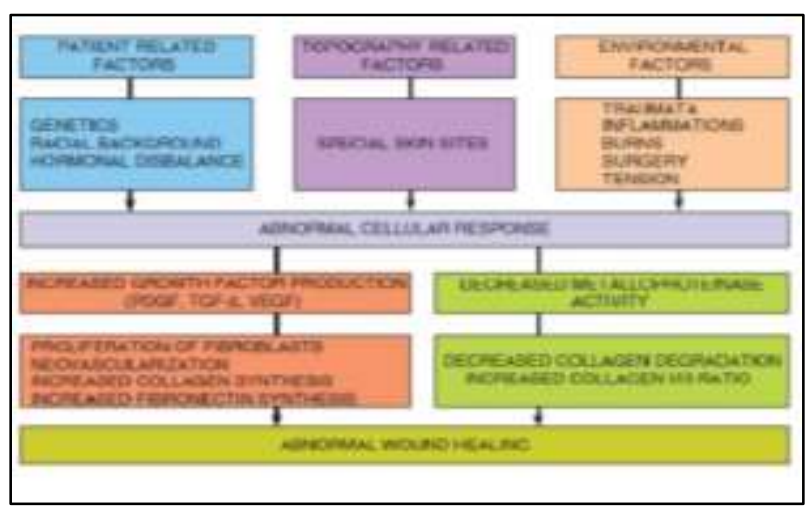

Figure 2: Pathogenesis of abnormal wound healing.

\section{Keloid scoring systems}

Vancouver scar scale (VSS)

The VSS, first described by Sullivan in 1990. It assesses 4 variables: vascularity, height/thickness, pliability, and pigmentation. Patient perception of his or her respective scars is not factored in to the overall score. VSS remains widely applicable to evaluate therapy and as a measure of outcome in burn studies. ${ }^{1-3}$

Patient and observer scar assessment scale (POSAS)

The POSAS includes subjective symptoms of pain and pruritus and expands on the objective data captured in the VSS. It consists of 2 numerical scales: The patient scar assessment scale and the observer scar assessment scale. It assesses vascularity, pigmentation, thickness, relief, pliability, and surface area and it incorporates patient assessments of pain, itching, colour, stiffness, thickness and relief.

\section{Manchester scar scale (MSS)}

The Manchester scar scale, proposed by Beausang et al. It assesses and rates seven scar parameters: scar colour (perfect, slight, obvious, or gross mismatch to surrounding skin), skin texture (matte or shiny), relationship to surrounding skin (range from flush to keloid), texture (range normal to hard), margins (distinct 
or indistinct), size $(<1 \mathrm{~cm}, 1-5 \mathrm{~cm},>5 \mathrm{~cm})$ and single or multiple.

\section{Therapy}

There is no universally accepted treatment resulting in permanent keloid scar reduction. Many treatments have been advocated, most of which have varying and transient success.

There is no single therapeutic modality that is best for all keloids. Location, size, and depth of the lesion, age of the patients; and past response to treatment determine the type of therapy used. ${ }^{4}$

\section{Steroid injections}

Intralesional steroid (triamcinolone acetonide) is the most effective and widely used treatment for keloids. Intralesional triamcinolone acetonide, a potent antiinflammatory hydrocortisone fluoridated at its ninth carbon, is first-line therapy for keloids.

Triamcinolone inhibits the proliferation of normal and keloid fibroblasts, inhibits collagen synthesis, increases collagenase production, and reduces levels of collagenase inhibitors. Working through fibroblast glucocorticoid receptors, steroids also induce ultra-structural changes in collagen synthesis that enhance the organization of collagen bundles and degenerate the characteristic keloidal collagen nodules. ${ }^{5-8}$

\section{Surgery}

Surgical excision of keloids by itself generally results in lesion recurrence, with recurrence rates of 40 to 100 percent. Simple excision is believed to stimulate additional collagen synthesis, resulting in rapid regrowth and often a larger keloid.

Various surgical techniques used for keloid excision are ${ }^{9}$

- Excisional surgery

- Excision with auto grafting

- Excision with auto flap (keloid fillet flap)

\section{Radiation}

Debeurmann and Guegorot first described the use of X rays in the treatment of keloids. ${ }^{10}$ Later evidence showed that radiation therapy alone is inadequate in the treatment of keloids; Cosman and colleagues introduced the use of post-operative radiation therapy as an adjunct to surgical excision. $^{11,12}$ Reported efficacy varied between 65 to $99 \%$ with excision alone. It is suggested that radiation affects fibroblast proliferation by inducing apoptosis. The main drawback of radiation therapy, aside from hyper pigmentation, is the risk of radiation- induced malignancy. ${ }^{13,14}$
Nevertheless, radiation therapy is contraindicated in children, as well as in areas of high carcinogenic potential, namely the breast and thyroid.

\section{Silicone gel}

Silicone gel, a U.S. food and drug administrationapproved, cross-linked polymer of dimethyl siloxane, is an effective adjunct to keloid excision and a prophylaxis to abnormal scarring in elective incisions.

\section{Pressure therapy}

Pressure therapy following excision is effective with minimal adverse effects, but its practical use is limited to earlobes. Prolonged pressure on the hypertrophic collagen has been reported to be effective in preventing recurrence of keloid after surgical treatment. ${ }^{15}$

\section{Laser}

The carbon dioxide laser has been well described for use in the treatment of keloids Lately pulsed dye laser (PDL) has been tried successfully for softening the lesions. Use of $\mathrm{Nd}$ : YAG laser as a monotherapy or in combination with intralesional triamcinolone injection has shown some promising results with a large percentage of patients remaining keloid-free at follow-up. ${ }^{16}$

\section{5-Fluorouracil}

Intralesional 5-fluorouracil is an experimental therapy for keloids that has shown some potential in preliminary trials.

5-Fluorouracil is an antimetabolite that inhibits fibroblast proliferation and modestly improves keloidal scarring. 5-Fluorouracil has been successfully used to inhibit postsurgical scarring in glaucoma surgery. Intralesional administration of 5-fluorouracil as single therapy for keloids has been reported in one retrospective study of more than 1000 patients where an initial response was almost uniformly present but was followed by recurrence, necessitating serial administrations. 5-Fluorouracil (50 $\mathrm{mg} / \mathrm{ml}$ ) was injected at $0.05 \mathrm{ml}$ per linear centimetre or until blanching appeared every 3 weeks up to 10 times. A small placebo-controlled prospective trial of surgical excision followed by topical administration of 5fluorouracil suggested clinical improvement in the treatment arm after 6 months of follow-up, along with a trend toward normalization of immunehistochemical markers. Wounds were exposed to a pledget soaked with 5 -fluorouracil $(50 \mathrm{mg} / \mathrm{ml})$ for 5 minutes, then closed. Adverse effects have been rare and include superficial skin irritation without any discernible hematologic changes. $^{17-18}$

Fitzpatrick has also reported his 9 years' experience of using a pyrimidine analog with anti-metabolite activity, 5-flurouracil (5-FU) $50 \mathrm{mg} / \mathrm{ml}$ with or without 
triamcinolone acetonide, in the treatment of keloids and hypertrophic scars. ${ }^{17}$

\section{Bleomycin}

Bleomycin in the dose of $1.5 \mathrm{IU} / \mathrm{ml}$ injected intralesionally through multiple pricks resulted in flattening of lesions in 6 out of 13 cases. ${ }^{19,20}$

\section{Interferon}

Intralesional interferon is an experimental therapy with considerable systemic adverse effects. Its efficacy in keloid management has not been demonstrated.

\section{Retinoids}

Retinoids, an experimental therapy, have produced responses in limited clinical trials, but there has been no general acceptance in clinical practice.

Topical and intralesional vitamin $\mathrm{A}$ and its retinoid derivatives enhance new wound healing and promote regression of pathologic scar tissue.

\section{Calcium channel blockers}

\section{Cryosurgery}

Cryosurgery uses rapid, repeated cooling and rewarming of tissue, leading to cell death and tissue sloughing. The efficacy of cryosurgery on keloids has been reported to range from 50 to 85 percent, with moderate flattening and symptomatic relief. ${ }^{21,22}$

\section{Antihistamine}

Penicillamine, $\beta$-aminopropionitrile, and colchicine

Imiquimod $5 \%$ cream

Vitamin A and E

Vitamin A lacks sufficient data and may be associated with side effects, especially in pregnant women. Finally, vitamin $\mathrm{E}$ alone may be detrimental to wound healing and often leads to contact dermatitis; it should, therefore, not be recommended. ${ }^{23}$

\section{Combination therapy}

The most effective management for keloids uses combination therapy, generally excision with adjuvant treatment.

- Surgery plus steroids

- Carbon dioxide laser plus steroids

- Surgery plus radiation therapy

- Surgery plus compression earrings

- $\quad$ Surgery plus silicone gel sheeting
- $\quad$ Surgery plus 5-fluorouracil

- Surgery plus imiquimod

\section{Possible future therapeutic agents 24}

Several possible treatments still in the experimental stage include hydroquinone, G6PD and hyperbaric oxygen.

\section{METHODS}

\section{Study population, location and duration}

Cases of clinically diagnosed keloids satisfying inclusion and exclusion criteria. in age group 10 to 70 years attending Dermatology OPD at South Central Railway Hospital, Secunderabad, in the period September 2012 to January 2014 were included in this study.

\section{Sample size}

A pilot study was conducted and a sample size of 70 with 35 in each group was calculated.

\section{Sampling technique}

Patients of age group 10-70 years suffering from keloids, fulfilling inclusion and exclusion criteria were included in the study. These patients were randomly allocated alternately between group 1 and group 2 .

\section{Design of study}

Interventional and comparative study (Comparing percentage reduction in volumes of Keloids between both groups after treatment).

\section{Inclusion criteria}

Clinically all cases of keloid among patients belonging to both sexes attending Dermatology OPD at Central Hospital, south central railways, Lallaguda, Secunderabad, India.

\section{Exclusion criteria}

- Pregnant and lactating women

- Age below 10 and above 70

- Immunosuppressed individuals

- Patients with extensive keloids following burns

- Patients with systemic illness like uncontrolled Diabetes mellitus, Hypertension, Mental disorder, Malignancy.

\section{Study Procedure}

A written informed consent was obtained prior to treatment. All patients in both groups were subjected to routine blood tests like complete blood picture, liver and 
renal function tests before starting and once after completion of treatment.

A total of 70 patients divided in to 35 in each group, group 1and group 2.One patient in group 1 withdrawn from treatment because of increased pain during treatment, another patient from group 1, two patients from group 2 stopped the course of treatment before completion, thus were excluded from study making group size 33 in each.

Using a vernier calipers maximum length $(\mathrm{L})$, breadth (B), height $(\mathrm{H})$ of keloid is measured at baseline and volume was calculated ( $\mathrm{Lx}$ B x H). Similarly volume was calculated at 9th week i.e, 1 week after completion of treatment. From these volumes percentage reduction in volume was calculated.

For group 1, injection 5-fluorouracil $0.9 \mathrm{ml}(50 \mathrm{mg} / \mathrm{ml})$ combined with $0.1 \mathrm{ml}$ of trimcinolone acetonide (40 $\mathrm{mg} / \mathrm{ml}$ ) [i.e., $45 \mathrm{mg}$ of 5-fluorouracil was combined with $4 \mathrm{mg}$ of triamcinolone acetonide (TAC)], was given weekly once for 8 weeks. It (TAC) is not expected to have any therapeutic efficacy but is employed for its effect on potential 5 Fluorouracil induced inflammation. ${ }^{25}$

For group 2, intralesional trimcinolone acetonide $(10 \mathrm{mg} / \mathrm{ml})$ alone at weekly intervals for 8 weeks was given. Volume of keloid was measured before starting treatment and 1 week after the $8^{\text {th }}$ injection. $\%$ reduction in volume was calculated.

Initially the keloid is cleaned with a spirit swab and allowed to dry. Now with a preloaded insulin syringe (30 gauze) drug is injected per $\mathrm{cm}^{2}$ area or till area injected blanches maximum dose being $2 \mathrm{ml}(100 \mathrm{mg})$ of 5-fluorouracil in group 1 and $2.5 \mathrm{ml}(25 \mathrm{mg})$ of Triamcinolone acetonide per injection. Such injections are repeated every week till 8 weeks in each group.

Pre-treatment and post treatment photographs were taken.

\section{Study tools}

Pre-treatment volume of keloid (length $\mathrm{x}$ breadth $\mathrm{x}$ height) and volume 1 week after completion of treatment i.e. $9^{\text {th }}$ week was recorded followed by calculation of percentage reduction in volume.

Predesigned proforma including demographics, detailed history, clinical examination and relevant laboratory investigations were used for patients recruited

Statistical analysis was done using student t-test.

\section{RESULTS}

The study was completed on 66 patients of keloids comprising two groups and the following observations were made.

\section{Inferential analysis}

- Comparison of $\%$ reduction in volume between 2 groups.

- Adverse effects

Table 2: Mean volume reduction of keloid in group 1 and group 2.

\begin{tabular}{|lcc|}
\hline Period & \multicolumn{1}{c}{$\begin{array}{c}\text { Group 1 } \\
\text { Mean volume (S.D) }\end{array}$} & $\begin{array}{c}\text { Group 2 } \\
\text { Mean volume(S.D) }\end{array}$ \\
\hline Pre treatment & 3641 (3241) & $3481(3147)$ \\
\hline Post treatment & $1244(1341)$ & $1551(1282)$ \\
\hline
\end{tabular}

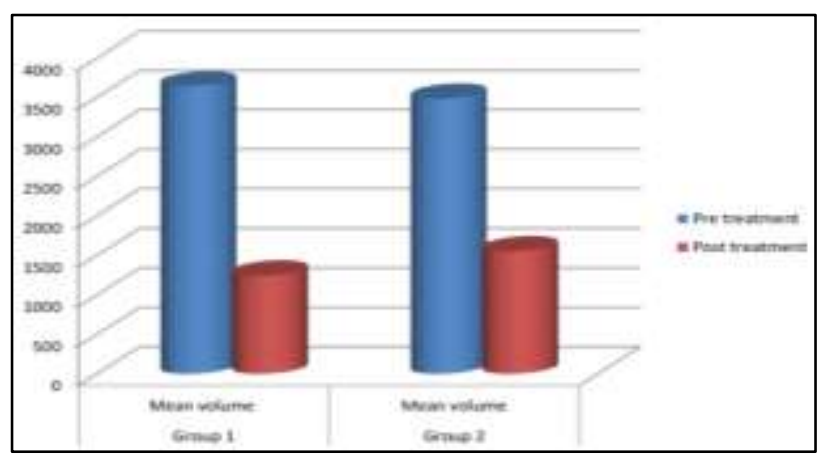

Figure 3: Bar diagram showing improvement in volume of keloid in both the groups.

Decrease in mean volume after treatment is seen in both the groups.

Table 3: Comparison of \% reduction in volume in both groups.

\begin{tabular}{|llll|}
\hline & $\begin{array}{l}\text { Group 1 } \\
\text { mean (SD) }\end{array}$ & $\begin{array}{l}\text { Group 2 } \\
\text { mean (SD) }\end{array}$ & $\begin{array}{l}\text { P } \\
\text { value }\end{array}$ \\
\hline $\begin{array}{l}\text { \% Reduction } \\
\text { in volume }\end{array}$ & $68.48(10.36)$ & $52.14(12.59)$ & $<0.01$ \\
\hline
\end{tabular}

$\%$ Reduction in volume is seen in both groups and is statistically significant. The mean $\%$ reduction was $68 \%$ in group 1 and $52 \%$ in group2. The improvement in volume is more in group 1 than group 2 which is statistically significant with $\mathrm{p}$ value $<0.01$.

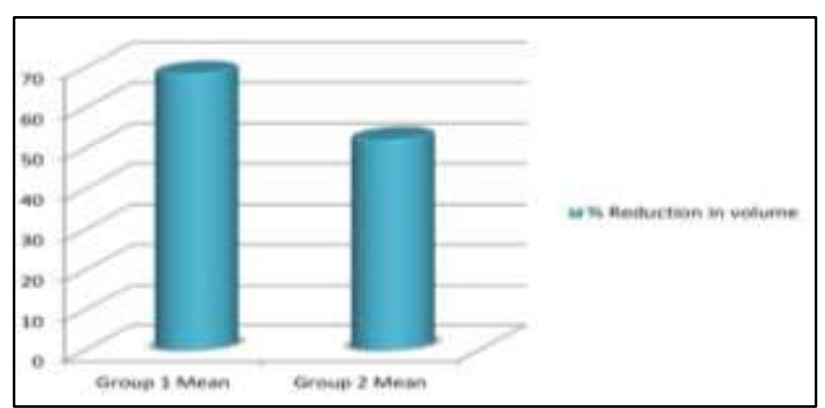

Figure 4: \% Reduction in volume between both groups. 
Table 4: Clinical response in keloids.

\begin{tabular}{|llll|}
\hline $\begin{array}{l}\text { Grade of } \\
\text { Improv- } \\
\text { ement }\end{array}$ & $\begin{array}{l}\text { \% reduction in } \\
\text { volume after } 8 \\
\text { injections }\end{array}$ & Group 1 & Group 2 \\
\hline Poor & Up to 25 & 0 & 0 \\
\hline Fair & $26-50$ & $2(6 \%)$ & $16(48.4 \%)$ \\
\hline Good & $51-75$ & $24(72.7 \%)$ & $16(48.4 \%)$ \\
\hline Excellent & $>75$ & $7(21 \%)$ & $1(3 \%)$ \\
\hline
\end{tabular}

Fair to good response was seen in most of the patients.

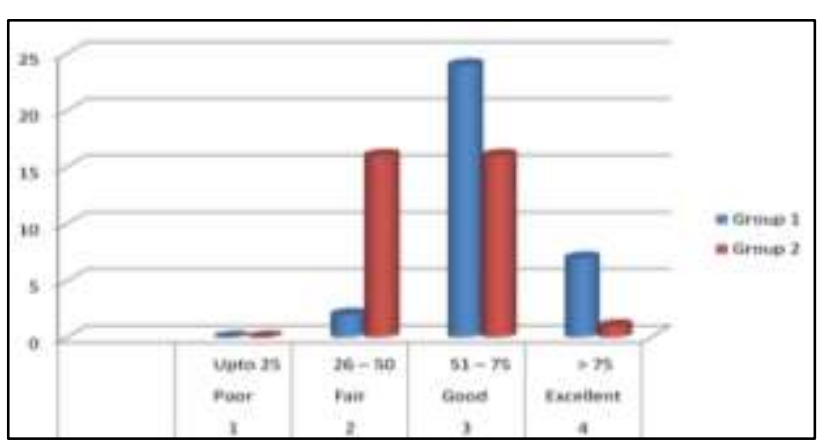

Figure 5: Clinical response in keloids.

Table 5: Adverse effects $(n=66)$.

\begin{tabular}{|lll|}
\hline Adverse effects & Group 1 & Group 2 \\
\hline Pain & $10(39.3 \%)$ & 0 \\
\hline Pain+ulcer & $5(15.15 \%)$ & 0 \\
\hline Hypo pigmentation & 0 & $2(6 \%)$ \\
\hline
\end{tabular}

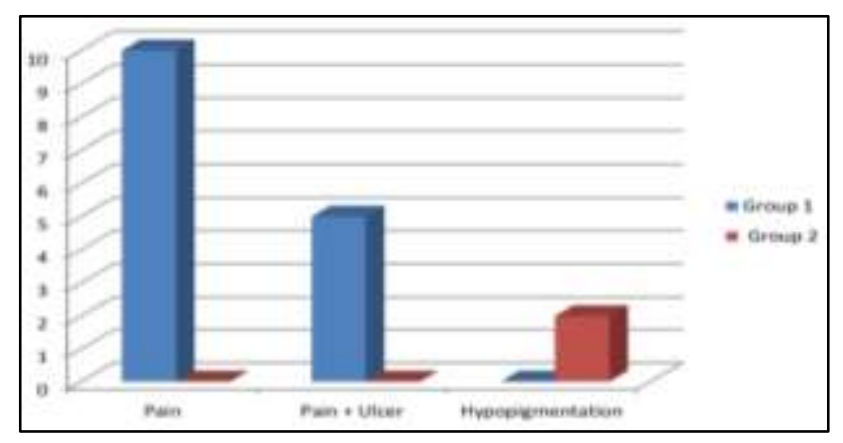

Figure 6: Adverse effects in both groups.

The above graph shows adverse effects are more in group 1 , pain being most common followed by pain with ulcer formation. However ulcer healed in about a week with topical antibiotic.

In group 2 only 2 patients developed hypo pigmentation as side affect others did not develop any side effects.

\section{DISCUSSION}

In this study trauma was the commonest factor seen in $38 \%$ of the patients followed by infection (24\%) and injury (24\%). Other causes were ear piercing, burns.
Factor such as trauma, tension and hormones have been associated with keloid formation. Trauma is the most frequently associated factor according to the study of Murray. ${ }^{25}$

Many theories have been advanced to explain the aetiology of keloid. In most patients, trauma was the major provoking factor in the study of Kelly. ${ }^{4}$ Infection has been also incriminated as a contributing factor in the formation of keloid in Kelly study. ${ }^{4}$ Even though some individuals may report spontaneous keloid formation, it may be that the initial skin wound that incited its development has been forgotten. ${ }^{26}$

In our study Trauma was most common predisposing factor as in study by Murray. ${ }^{25}$

\section{Response of patients to respective regimens}

In the present study, the primary outcome evaluated was the percentage of reduction in volume of keloid, as a main parameter of efficacy.

Table 6: Group 1 response to 5-fluorouracil with triamcinolone acetonide.

\begin{tabular}{|llll|}
\hline $\begin{array}{l}\text { Response to } \\
\text { treatment }\end{array}$ & $\begin{array}{l}\text { Present } \\
\text { study }\end{array}$ & $\begin{array}{l}\text { Nanda } \\
\text { et al }\end{array}$ & $\begin{array}{l}\text { Gupta } \\
\text { et al }\end{array}$ \\
\hline Poor $(<25 \%)$ & 0 & $7.1 \%$ & $16.6 \%$ \\
\hline Fair $(26-50 \%)$ & $6 \%$ & $14.3 \%$ & $25 \%$ \\
\hline Good $(51-75 \%)$ & $73 \%$ & $71.4 \%$ & $25 \%$ \\
\hline Excellent $(76-100 \%)$ & $21 \%$ & $7.1 \%$ & $33 \%$ \\
\hline
\end{tabular}

Group 1: Intralesional 5-fluorouracil (with triamcinolone acetonide)

Out of 33 patient , 24 (73)\% showed good response followed by excellent response in $7(21 \%)$ patients, fair response in $2(6 \%)$ patients and no patients showed poor response.

In Nanda et al study majority of patients i.e., $71.4 \%$ patients showed good response, followed by $14.3 \%$ fair response, $7.1 \%$ excellent response and $7.1 \%$ patients showed poor response. $^{26}$

In Gupta et al study, out of 24 patients $8(33 \%)$ patients showed an excellent outcome, $6(25 \%)$ patients each showed good and fair response and 4 (16.6\%) patients showed a poor response. The symptoms disappeared in 17 $(70.8 \%)$ patients and improved in $3(12.5 \%)$ patients. $^{27}$

Kontochristopoulos et al in his study found that out of 20 patients, $17(85 \%)$ patients showed more than $50 \%$ improvement. $^{28}$

Darougheh et al in his study patient's self-assessment at end of study showed $>50 \%$ improvement in $55 \%$ patients among Group 1. ${ }^{29}$ 
Asilian et al in his study showed $>50 \%$ improvement in $40 \%$ patients in Group $1 .^{30}$

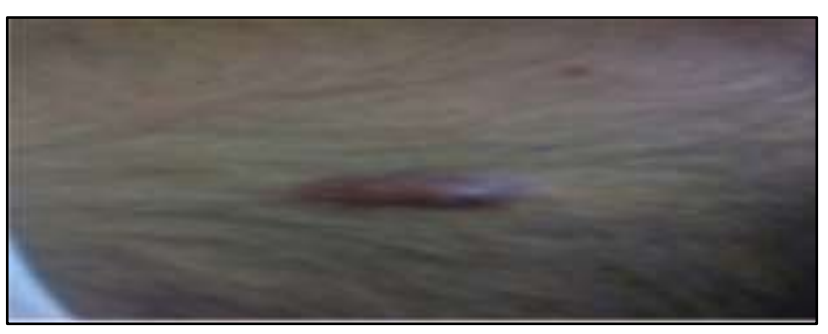

Figure 7: Before 5-fluorouracil with TAC (group 1).

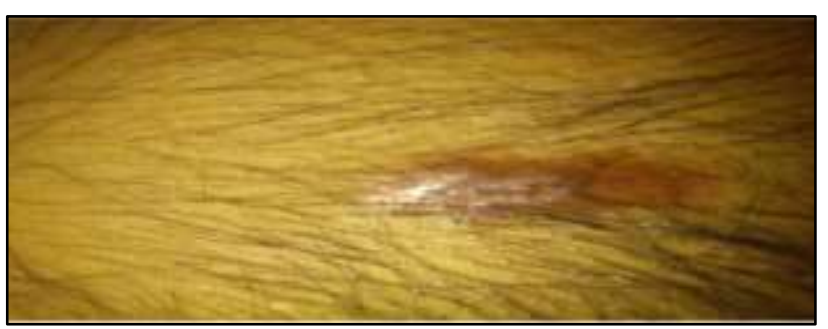

Figure 8: After 5-FU with TAC (group 1).

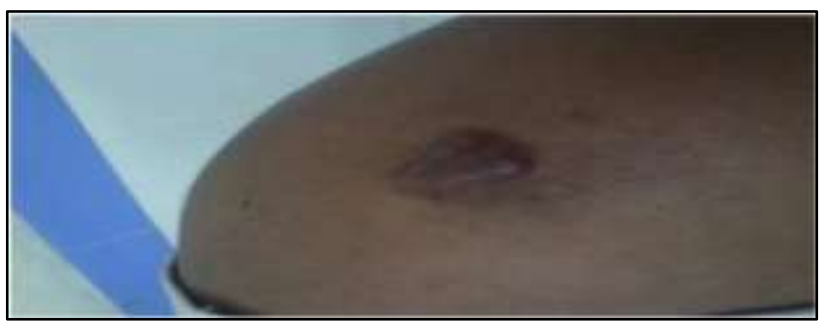

Figure 9: Keloid before 5-FU+TAC (group 1).

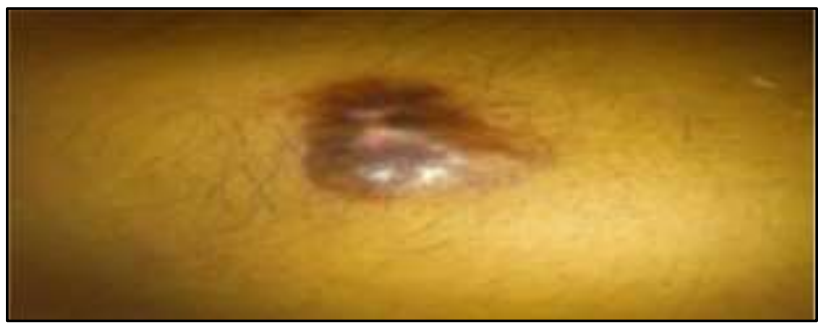

Figure 10: Keloid after 5-FU+TAC (group 1).

Figure 11: Ear keloid before 5-FU+TAC (group 1)??????????

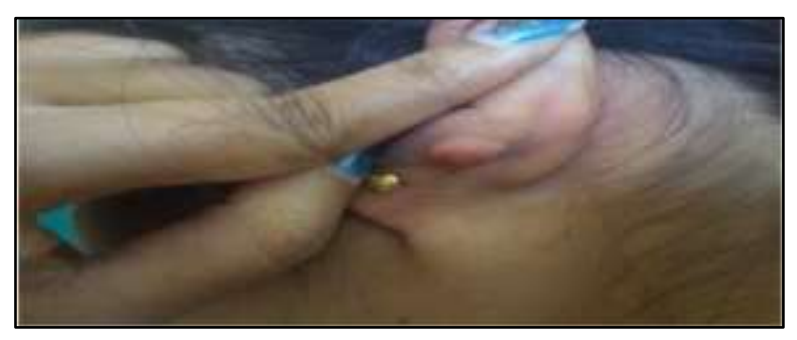

Figure 12: Ear keloid after 5-FU+TAC (group 1).
Table 7: Group 2 response to intralesional triamcinolone acetonide.

\begin{tabular}{|ll|l|}
\hline $\begin{array}{l}\text { \% reduction in } \\
\text { volume }\end{array}$ & Present study & Asilian et al \\
\hline$>50 \%$ & $51.4 \%$ & $15 \%$ \\
\hline
\end{tabular}

Group 2: Intralesional triamcinolone acetonide

Out of 33 patients $1(3 \%)$ patients showed excellent response followed by good and fair response in 16 (48.4\%) patients each. All patients had relief of symptoms.

Darougheh A. et al in his study patients self-assessment at end of study showed $>50 \%$ improvement $20 \%$ patients in Group 2. ${ }^{29}$

Asilian et al in his study reported $>50 \%$ improvement in $15 \%$ patients treated with Triamcinolone Acetonide $(10 \mathrm{mg} / \mathrm{ml})$ weekly for 8 weeks. ${ }^{30}$

Brain et al in his study found that use of intralesional triamcinolone acetonide (10-40 $\mathrm{mg} / \mathrm{ml})$ injection, was associated with significant response rate in $50-100 \%$ of cases. $^{31}$

In the study of Griffith patients treated with triamcinolone acetonide showed complete flattening of lesions in $19(51 \%)$ patients and partial dissolution (softening) in 15 $(40 \%)$ patients. In all instances there was relief of symptoms. ${ }^{5,37}$

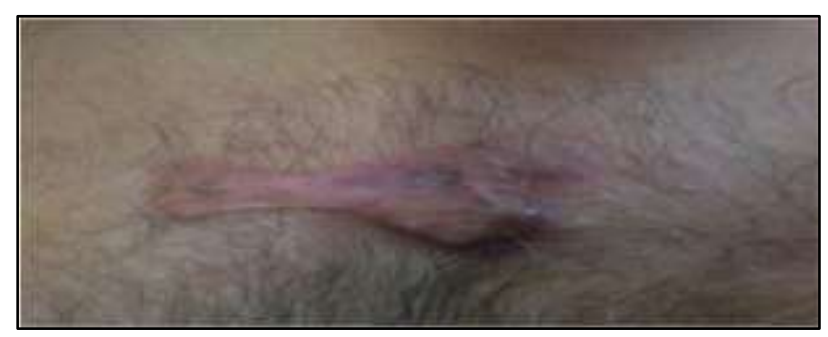

Figure 13: Keloid before TAC (group 2).

Table 8: Treatment outcome in 2 groups.

\begin{tabular}{|lll|l|}
\hline $\begin{array}{l}\text { Grade of } \\
\text { Impro- } \\
\text { vement }\end{array}$ & $\begin{array}{l}\text { \% reduction in } \\
\text { volume after } 8 \\
\text { injections }\end{array}$ & Group 1 & Group 2 \\
\hline Poor & Upto 25 & 0 & 0 \\
\hline Fair & $26-50$ & $2(6 \%)$ & $16(48.4 \%)$ \\
\hline Good & $51-75$ & $24(72.7 \%)$ & $16(48.4 \%)$ \\
\hline Excellent & $>75$ & $7(21 \%)$ & $1(3 \%)$ \\
\hline
\end{tabular}

Treatment outcome in 2 groups

The above tables indicate $\%$ reduction in volume was seen in both groups, but it was more in group 1 compared 
to group 2 which was statistically significant, with $\mathrm{p}$ value $<0.01$.

Darougheh A et al and Asilian et al also in their studies had better improvement with TAC+5-FU than TAC alone which was statistically significant with a pvalue $<0.05$. $^{29-30}$

Thus the present study coincides with the above studies with respect to improvement in size of keloid.

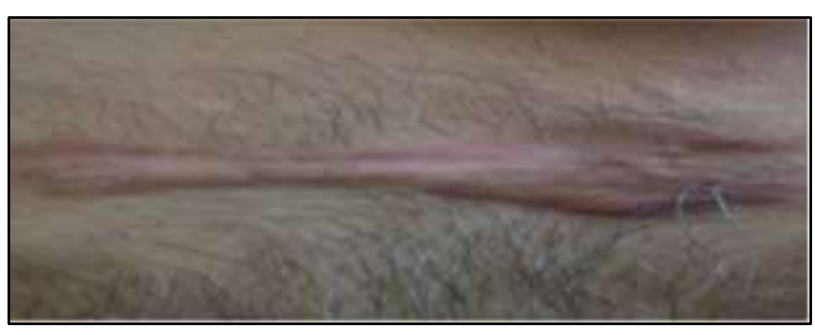

Figure 14: Keloid after TAC (group 2).

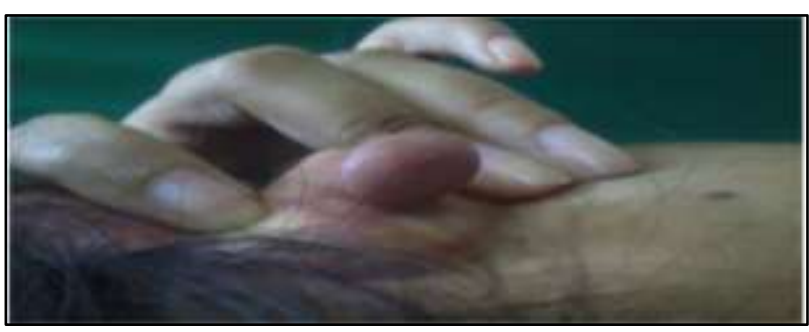

Figure 15: Ear keloid before TAC (group 2).

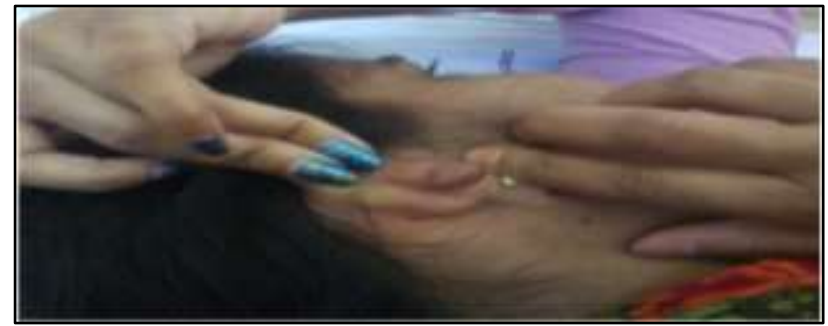

Figure 16: Ear keloid after TAC (group 2).

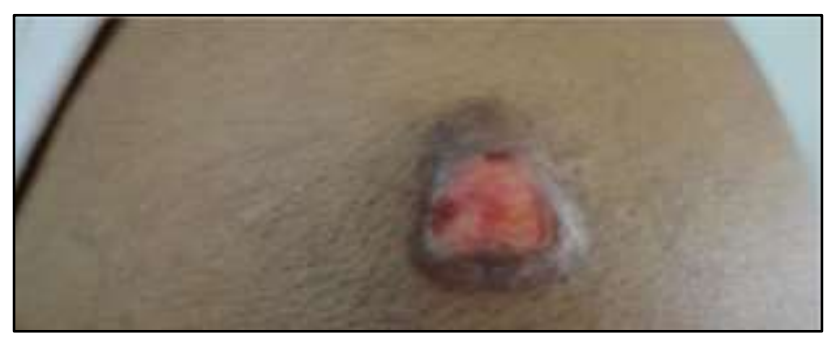

Figure 17: Ulcer occuring during treatment with intralesional 5-fluorouracil.

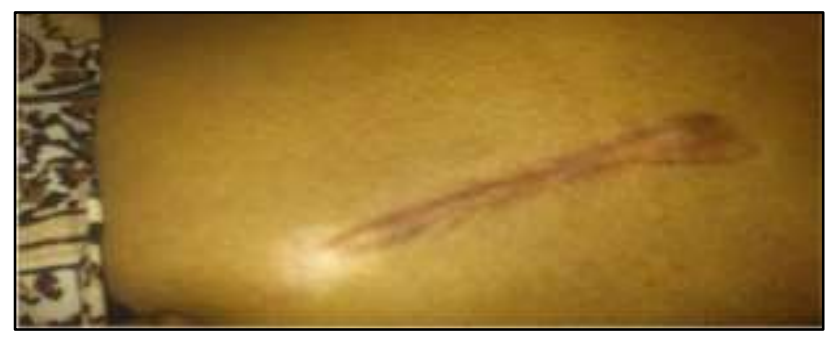

Figure 18: Hypopigmentation as adverse effect to intralesional triamcinolone acetonide alone.

Table 9: Comparison of adverse effects between studies.

\begin{tabular}{|lllll|}
\hline Adverse effects & & Group 1 & Group 2 \\
\hline Present study & Pain & Pain+Ulcer & Hypopig & Atrophy and telangiectasia \\
\hline Darougheh A. et al & $39.3 \%$ & $15.15 \%$ & $6 \%$ & - \\
\hline
\end{tabular}

The above table shows adverse effects are less in the present study in both groups when compared to A. Darougheh et al study but is statistically significant with $\mathrm{p}$ value $<0.05(0.02){ }^{29}$

\section{CONCLUSION}

- The present comparative study has shown that the intralesional injection of 5-flourouracil combined with triamcinolone acetonide is more effective (statistically significant with $\mathrm{p}$ value $<0.01$ ) than intralesional injection of triamcinolone acetonide alone in reducing size of keloid.

- According to standard deviation and mean of both groups in percentage reduction of volume, sample size required is 10 in each group with $\alpha=0.05$ and power $(1-\alpha)=0.8$. Thus sample size selected is justified in both groups.

- Adverse effects were found to be less in present study except for ulcer formation which is found to be more.

\section{ACKNOWLEDGEMENTS}

The authors are express sincere gratitude to the Department of Dermatology, Railway Hospital , South Central Railway for the extensive cooperation rendered for carrying out this work. They thank the Administration for all the help rendered. Dr Ketan statistician for his helping hand in statistical analysis. We thank our patients for their cooperation and consent. 
Funding: No funding sources

Conflict of interest: None declared

Ethical approval: The study was approved by the Institutional Ethics Committee

\section{REFERENCES}

1. Nedelec B, Shankowsky A, Tredgett EE. Rating the resolving hypertrophic scar: comparison of the Vancouver Scar Scale and scar volume. J Burn Care Rehabil. 2000;21:205-12.

2. Sullivan T, Smith J, Kermode J, Mclver J, Courtemanche DJ. Rating the burn scar. J Burn Care Rehabil. 1990;11:256-60.

3. Lye I, Edgar DW, Wood FM, Carroll S. Tissue tonometry is a simple, objective measure for pliability of burn scar: is it reliable? J Burn Care Res 2006;27:82-5.

4. Kelly AP. Keloids. Dermatol Clin. 1988;6:413-24.

5. Griffith BH. The treatment of keloids with triamcinolone acetonide. Plast Reconstr Surg. 1966;38:202-8.

6. Ketchum LD, Smith J, Robinson DW, Masters FW. The treatment of hypertrophic scar, keloid and scar contracture by triamcinolone acetonide. Plast Reconstr Surg. 1966;38:209-18.

7. Ketchum LD, Robinson DW, Masters FW. Follow-up on treatment of hypertrophic scars and keloids with triamcinolone. Plast Reconstr Surg. 1971;48:256-9.

8. Ritota PC, Lo AK. Cushing's syndrome in postburn children following intralesional triamcinolone injection. Ann Plast Surg. 1996;36:508-11.

9. Savant S. Hypertrophic scars and keloids. In: Textbook of dermatosurgery and cosmetology. $2^{\text {nd }} e d$. Mumbai: ASCAD; 2008:316-30.

10. DeBeurmann R, Gougerot GH. Cheloids des musquescies. Ann Dermatol Syphilol. 1906;7:151.

11. Borok TL, Bray M, Sinclair I. Role of ionizing irradiation for 393 keloids. Int J Radiat Oncol Biol Phys. 1988;15:865-70.

12. Cosman B, Crikelair GF, Ju DM. The surgical treatment of keloids. Plast Reconstr Surg. 1961;27:335-58.

13. Van den Brenk HA, Minty CC. Radiation in the management of keloids and hypertrophic scars. Br J Surg. 1960;47:595-605.

14. Malaker K, Vijayraghavan K, Hodson I, Al Yafi T. Retrospective analysis of treatment of unresectable keloids with primary radiation over 25 years. Clin Oncol. 2004;16:290-8.

15. Al-Attar A, Mess S, Thomassen JM, Kauffman CL, Davison SP. Keloid pathogenesis and treatment. Plast Reconstr Surg. 2006;117:286-300.

16. Uppal RS, Khan U, Kakar S, Talas G, Chapman P, Mc Grouther AD. The effects of a single dose of 5- fluorouracil on keloid scars: A clinical trial of timed wound irrigation after extralesional excision. Plast Reconstr Surg. 2001;108:1218-24.

17. Fitzpatrick RE. Treatment of inflamed hypertrophic scars using intralesional 5 -FU. Dermatol Surg. 1999;25:224-32.

18. Manuskiatti W, Fitzpatrick RE. Treatment response of keloidal and hypertrophic sternotomy scars: Comparison among intralesional corticosteroid, 5fluorouracil, and 585-nm flashlamp-pumped pulseddye laser treatments. Arch Dermatol. 2002;138:114-55.

19. Espana A, Solano T, Quintanilla E. Bleomycin in the treatment of keloids and hypertrophic scars. Dermatol Surg. 2001;27:23-7.

20. Bodokh I, Brun P. The treatment of keloids with intralesional Bleomycin. Ann Dermatol Venereol. 1996;123:791-4.

21. Gupta S, Kumar B. Intralesional cryosurgery using lumbar puncture and or hypodermic needles for large, bulky, recalcitrant keloids. Int $\mathrm{J}$ Dermatol. 2001;40:349-53.

22. Malakar S, Malakar R. Intralesional cryosurgery: Consequences, cautions and precautions. Indian $\mathrm{J}$ Dermatol. 2000;45:100-1.

23. Zurada JM, Kriegel D. Topical treatments for hypertrophic scars. J Am Acad Dermatol. 2006;55:1024-31.

24. Kelly AP: Update on the management of Keloids. Semin Cutan Med Surg. 2009;28:71-6

25. Murray JC. Scars and keloids. Dermatol Clin. 1993;11:697-708.

26. Nanda S, Reddy BS. Intralesional 5-fluorouracil as a treatment modality of keloids. Dermatol Surg. 2004;30:56-7.

27. Gupta S, Kalra A. Efficacy and safety of intralesional 5-fluorouracil in the treatment of keloids. Dermatology. 2002;204:130-2.

28. Kontochristopoulos G, Stefanaki C, Panagiotopoulos A, Stefanaki K, Argyrakos T, Petridis A, et al. Intralesional 5-fluorouracil in the treatment of keloids: an open clinical and histopathologic study. J Am Acad Dermatol. 2005;52:474-9.

29. Darougheh A, Asilian A, Shariati F. Intralesional triamcinolone acetonide alone or in combination with 5 -flourouracil for the treat ment of keloid and hypertrophic scars. Clin Exp Dermatol. 2009;34:219-23.

30. Darougheh A, Asilian A, Shariati F. New combination of triamcinolone, 5-flourouracil and pulsed dye laser for treatment of keloid and hypertrophic scars. Dermatol Surg. 2006;32:907-15.

31. Berman B, Bieley HC. Keloids. J Am Acad Dermatol. 1995;33:117-23.

Cite this article as: Nagarur K, Raja NR. A comparative study between intralesional 5fluorouracil combined with triamcinolone acetonide and triamcinolone acetonide alone in the treatment of keloids. Int J Basic Clin Pharmacol 2016;5:1090-8. 